\title{
Challenges in Developing Urban Marketing Strategies: Evidence From Ekaterinburg ${ }^{1}$
}

2018 FIFA World Cup became the first championship held in Russia and Eastern Europe. However, at that time, Russia already had experience in hosting sports mega-events such as the 2014 Winter Olympics in Sochi, the 2013 Summer Universiade in Kazan, and before that the 1980 Olympic Games in Moscow. Hosting the championship in 11 cities at once sets the 2018 FIFA World Cup apart from all these events. It gave impetus to the socio-economic development of all cities (and regions) where the matches were held, including Ekaterinburg. On the other hand, the sports mega-event provides unique opportunities for the global marketing positioning of the city. The present study examines the challenges of developing a city marketing strategy using the case of Ekaterinburg. Theoretical foundations of place marketing were employed for the analysis. Based on the critically explored concepts of place marketing and the competitiveness of the territory, the author's $4 C+1 S$ model was constructed. The current state of the urban environment was evaluated using a $S W O T$ analysis conducted in a group of students. The research also analysed cities' experience in conducting recent sports mega-events in the world and managing their facilities and infrastructure after these events. In conclusion, we formulated the proposals for Ekaterinburg's positioning, including the improvement of the transport system, solution to environmental problems, increase in the effectiveness of the local government, and maintenance of public consensus. As a basis for specialisation, it is suggested to consider either the industry of meetings (MICE) or industrial tourism with complementary 'natural' and 'historical' directions. The proposed $4 C+1 S$ model can be used as a methodological framework for the creation of urban marketing strategies. Additionally, the article makes a theoretical contribution to the development of place marketing. The results can be applied in further academic urban studies.

Keywords: place marketing, urban marketing, city marketing, positioning, place branding, city branding, regional competitiveness, 2018 FIFA, Ekaterinburg, Russia

\section{Acknowledgments}

The article has been prepared with the support of the Russian Foundation for Basic Research, project 18-00-01040 KOMFI "The Impact of Emerging Technologies on Urban Environment and the Quality of Life of Urban Communities". The authors would also like to express their deepest gratitude to the anonymous reviewers, whose comments certainly made this work better.

For citation: Kochetkov, D. M., Vuković, D. B. \& Kondyurina, E. A. (2021). Challenges in Developing Urban Marketing Strategies: Evidence From Ekaterinburg. Ekonomika regiona [Economy of regions], 17(4), 1137-1150, https://doi.org/10.17059/ekon. reg.2021-4-7

\footnotetext{
1 @ $\Subset$ Kochetkov D. M., Vuković D. B., Kondyurina E. A. Text. 2021.
} 
ИССЛЕДОВАТЕЛЬСКАЯ СТАТЬЯ

Д. М. Кочетков ${ }^{\text {a) }}$, Д. Б. Вукович ${ }^{\text {) }}$, Е. А. Кондюрина ${ }^{\text {() }}$

а) Министерство науки и высшего образования Российской Федерации, Москва, Российская Федерация

6) Географический институт «Йован Цвиджич» Сербской академии наук и искусств, Белград, Сербия

в) Покровский пассаж, Екатеринбург, Российская Федерация

a) https://orcid.org/0000-0001-7890-7532,e-mail: kochetkovdm@hotmail.com

6) http://orcid.org/0000-0002-1165-489X

в) https://orcid.org/0000-0001-6537-1978

\section{Проблемы разработки маркетинговых стратегий города: опыт Екатеринбурга}

Чемпионат мира по футболу 2018 г. стал первым чемпионатом, проведенным в России и Восточной Европе. На тот момент у России уже был опыт проведения таких спортивных мега-событий, как зимние Олимпийские игры 2014 2. в Сочи, летняя Универсиада 2013 г. в Казани, а также Олимпийские игры 1980 г. в Москве. Проведение матчей Чемпионата мира сразу в 11 российских городах, в число которых входит Екатеринбург, позитивно повлияло на социально-экономическое развитие данных городов (а также регионов). Подобное спортивное мегасобытие предоставляет уникальные возможности для маркетингового позиционирования города в мировом пространстве. В статье проанализированы проблемы разработки маркетинговой стратегии города на примере Екатеринбурга. На основе исследованных концепций маркетинга мест и конкурентоспособности территории была построена авторская модель $4 C+1 S$. Современное состояние городской среды было оценено при помощи SWOTанализа, проведенного среди студентов. Также в ходе исследования был изучен мировой опыт городов в проведении спортивных мегасобытий и управлении объектами инфраструктуры после этих событий. В заключении статьи сформулированы предложения по позиционированию Екатеринбурга, включающие в себя улучшение транспортной системы, решение экологических проблем, повышение эффективности местного самоуправления и поддержание общественного консенсуса. В качестве туристической специализации Екатеринбурга были предложены два направления: деловой туризм или промышленный туризм с вовлечением «природных» и «исторических» аспектов. Представленная модель $4 C+1 S$ может быть использована в качестве методологии для разработки маркетинговых стратегий города. Кроме того, статья вносит вклад в развитие маркетинга мест. Полученные результаты могут быть применены в дальнейших исследованиях в сфере урбанистики.

Ключевые слова: маркетинг мест, городской маркетинг, позиционирование, территориальный брендинг, брендинг города, региональная конкурентоспособность, ФИФА 2018, Екатеринбург, Россия

\section{Благодарности}

Статья подготовлена при поддержке Российского фонда фундаментальных исследований, проект 18-00-01040 КОМФИ «Влияние новых технологий на городскую среду и качество жизни городских сообществ». Авторы также выражают глубочайшую благодарность анонимным рецензентам, чьи комментарии позволили улучшить качество работьь.

Для цитирования: Кочетков Д. М., Вукович Д. Б., Кондюрина Е. А. Проблемы разработки маркетинговых стратегий города: опыт Екатеринбурга // Экономика региона. 2021. Т. 17, вып. 4. С. 1137-1150. https://doi.org/10.17059/ekon. reg.2021-4-7.

\section{Introduction}

Recently, the final match of FIFA 2018 in Russia ended. While some people call this World Cup the best in history, there are also critics. Certainly, one thing can be said for sure: a sports event of such scale transforms the cities in which the matches are played. It is especially applicable to regional cities, which, without exaggeration, have received a new impetus in their development. Ekaterinburg entered the list of 11 Russian cities that hosted FIFA 2018 matches. The city has changed significantly: the roads have been repaired, the central stadium and the railway station have been reconstructed. Tens of thousands of foreign guests have visited it. However, the significance of the World Cup for the city is not only and not so much in the surge of tourist activity, but in the opportunity to convey the message to the global audience. Such a message should encourage people around the world to spend a vacation here, as well as attract foreign investors interested in Ekaterinburg's business prospects.

There are many points of view of experts, government officials and just active citizens on the further development of the city, and it is good that the urban development strategy is a subject of public discussion. At the same time, the lack of precise positioning gives rise to the ambiguity 


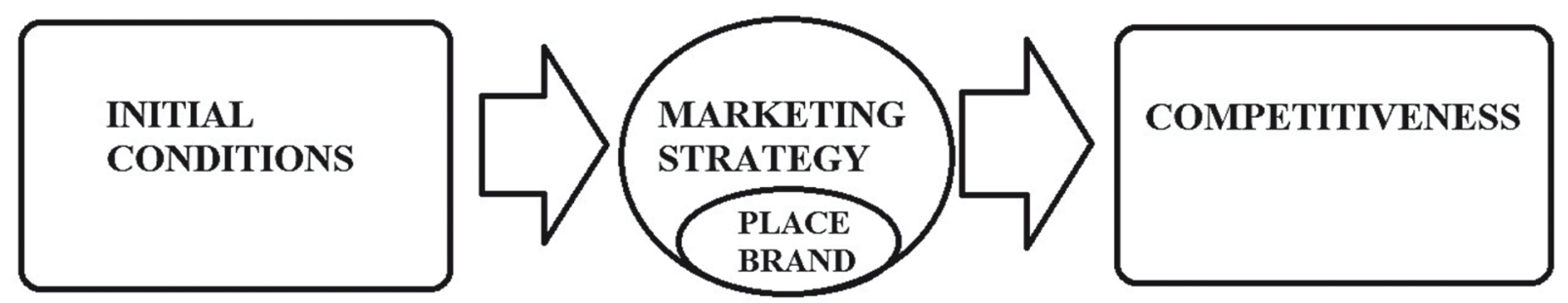

Fig. 1. A conceptual scheme for place marketing

of message for external audiences. As part of this study, we would like to consider the problem from the perspective of place marketing. Our reasoning is mainly related to the city, but it is also applicable to the regional level. In the next section, we briefly formulated the conceptual foundations for place marketing analysis, as well as that of urban competitiveness; then, we presented the authors' model $4 \mathrm{C}+1 \mathrm{~S}$. We also analysed the experience of the latest sports mega-events in the world and the management of their facilities and infrastructure after these events. In conclusion, we formulated some proposals for the positioning of Ekaterinburg.

\section{Theoretical Background}

\section{Conceptual Basis of Place Marketing}

In the past two decades, a lot has been written about place marketing. Nevertheless, most of these studies are just case analysis. Therefore, in this research area, the theory lags behind the practice, dictating the need for further work on the field conceptualisation and development of theoretical and methodological tools. Some of the most significant studies examine:

- Conceptualisation of urban marketing and urban competitiveness [1].

- Comparison of needs and preferences of 'creative' and 'non-creative' classes in the context of place branding [2].

- The survey of 878 residents of the city of Gold Coast and testing of 10 hypotheses regarding the antecedents of the city brand [3].

- The approach to place branding, based on the identity of the place [4].

- The role of the local population in the place branding [5]. [6].

- Social networks as an urban marketing tool

We understand place marketing as a marketing process aimed at creation, development, and active promotion and utilisation of competitive advantages of a particular place in its interests, i.e., the interests of its internal and external stakeholders [7]. The key actor in place marketing is the municipal (regional) authorities.
The main task of place marketing is to increase the competitiveness of the territory. This aspect can be interpreted in various ways as an increase in the investment attractiveness of the place, improvement of the regional infrastructure, creation of a favourable image of the place, promotion of the brand, and development of favourable conditions for living, working, and attracting external tourists. The concept of competitiveness will be discussed later in the paper. Achievement of the tasks of place marketing depends on the optimal use of territory resources and potential, as well as on the cooperation between all stakeholders.

Stakeholders can be both residents and non-residents of the territory, whose interests and resources can influence its development. They have their specific perception of the place and its products, as well as their interests and priorities, prone to change. The well-being of stakeholders in the consumption of urban (regional) resources, products, services, and opportunities increases the welfare of the city (region). The territory is a value for each stakeholder. A universal measure of the place's consumer performance, unanimously accepted by all stakeholders, is the sustainable development of the territory, even though the satisfaction of different stakeholders with its development may differ (Fig. 1) ${ }^{1}$.

The brand is the basis of the place marketing strategy; at the same time, it is an exclusively endogenous phenomenon. Brand values are not constructed arbitrarily; specialists identify them in the process of studying the lifestyle and everyday culture of the place. A place brand generating active communications cannot be designed and implemented by external coercion: it already exists in a hidden form in the given location. The task of experts is to identify and strengthen it [8].

Sustainable development of the place is due to an increase in its competitiveness. The competitiveness of the territory is the object of place marketing. Places compete for investors, tourists, markets, and such factors as natural, human, or economic resources. All these factors form the

\footnotetext{
${ }^{1}$ All figures and tables in the text are the development of the authors unless otherwise indicated.
} 


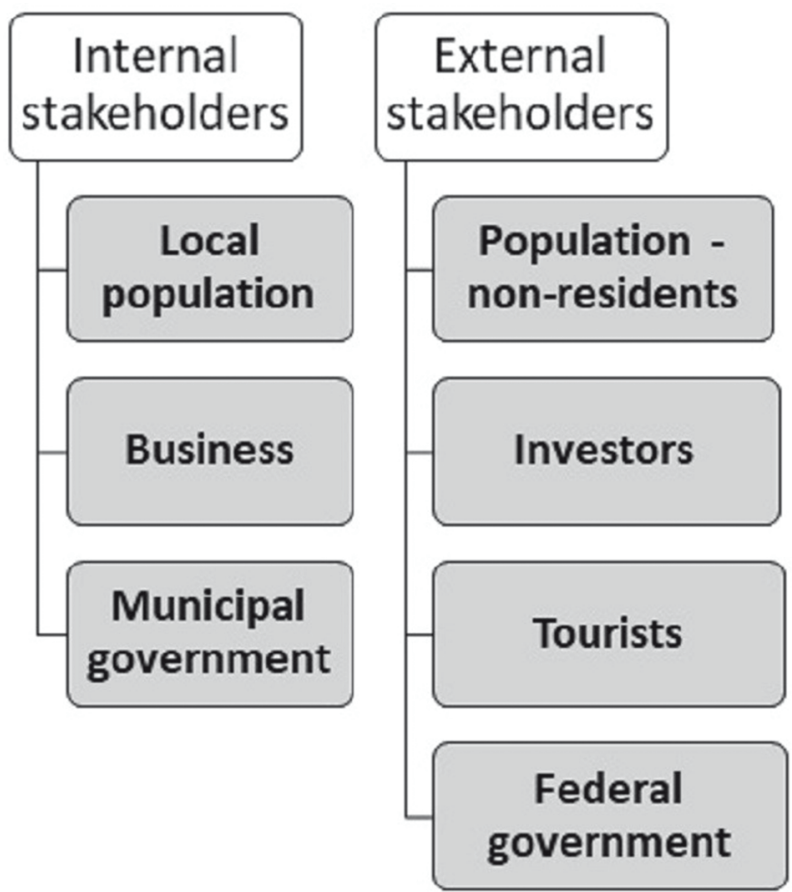

Fig. 2. Stakeholder map

competitive advantages of the place (basis of its competitiveness) and determine its development prospects. The main assets of the territory are its resources. Those regions that can effectively use them occupy stable positions. There is a relationship between the place image and reputation and its attractiveness for investment, life, and tourism. Development of the city (region) image and promotion of the place brand is facilitated by a complex process of analysing the strengths and weaknesses of the place as compared to competitors, generation, effective use, and promotion of competitive advantages, as well as engagement and reconciliation of the conflicting stakeholder interests.

Understanding and consideration of the interests and expectations of significant stakeholders is required to determine priorities and create development programmes for any place since their satisfaction affects the attractiveness and competitiveness of the place. However, when drawing up development plans, it is necessary to strike a balance so that any stakeholder interests do not violate the sustainability of the place development as a whole (Fig. 2, Table 1). External stakeholders include federal government bodies, investors, tourists, population (non-residents - migrants). Internal stakeholders include the local community, local governments, and entrepreneurs.

Two things should be noted. First, the interests of different stakeholders often coincide (for example, residents and non-residents, federal and local authorities, investors, and local businesses). Second, in the context of a redistributive economy in Russia (the majority of taxes go to the federal budget), the satisfaction of federal authorities with the current situation in the region is often crucial. Thus, the administrative resource of the authorities can be added to the list of assets of the place.

\section{The Notion of Urban (Regional) Competitiveness}

The discourse of competitiveness at the macroeconomic level goes back to Michael Porter.

Stakeholder interests

\begin{tabular}{|c|c|c|}
\hline Stakeholder & Type & Interests \\
\hline Local population & Internal & $\begin{array}{l}\text { Comfortable and safe conditions for living, recreation, self-expression, and economic } \\
\text { activity; } \\
\text { Available jobs, developed infrastructure and efficient transport interchanges; } \\
\text { Favourable environmental conditions }\end{array}$ \\
\hline Business & Internal & $\begin{array}{l}\text { Increase in financial well-being; } \\
\text { Expansion of operationsAvailability of modern technologies; } \\
\text { Availability of human resources; } \\
\text { Favourable legal and tax environment }\end{array}$ \\
\hline $\begin{array}{l}\text { Municipal } \\
\text { government }\end{array}$ & Internal & $\begin{array}{l}\text { Growth in budget revenues; } \\
\text { Growth in production and sales of goods, works and services; } \\
\text { Increase in the competitiveness of the place; } \\
\text { Stable social situation }\end{array}$ \\
\hline $\begin{array}{l}\text { Population } \\
\text { - non-residents }\end{array}$ & External & $\begin{array}{l}\text { High income; } \\
\text { Employment and housing }\end{array}$ \\
\hline Investors & External & Return on investment \\
\hline Tourists & External & $\begin{array}{l}\text { Comfortable and safe conditions for temporary residence; } \\
\text { Developed infrastructure; } \\
\text { Access to cultural and entertainment events, historical sites }\end{array}$ \\
\hline $\begin{array}{l}\text { Federal } \\
\text { government }\end{array}$ & External & $\begin{array}{l}\text { Stability of revenues to the federal budget; } \\
\text { Stable social situation }\end{array}$ \\
\hline
\end{tabular}


In his influential work 'Competitive Advantage of Nations' [9], Porter applied his concept of the strategic advantage of firms and industries to the analysis of the competitive position of nations. He argued that the new paradigm of competitive advantage replaced the outdated Ricardian theory of comparative advantages. In what conditions do firms and industries achieve international success in specific sectors and industries? The search for these conditions represents the national (regional, urban) strategy of competitive advantage. Porter considered productivity as the only basis of national competitiveness [10]. Unfortunately, Porter's definitions were not clear enough, which led to criticism of his theory. The leading critic of Porter was Paul Krugman [11, 12].

However, the concept of competitiveness at the macro level spread very quickly in the academic community, especially among the 'new regionalists' [13-16]. A considerable amount of literature on urban competitiveness appeared in parallel with the development of the concept of regional competitiveness [17-21]. Even though the conceptual framework for the competitiveness of cities was developed simultaneously with regional competitiveness, the content of the concepts is somewhat different.

Peter Kresl highlights six attributes of a highly competitive urban economy [22, p. 51]: jobs.

- Creation of high-tech and high-revenue

- Produced goods and services that have an environmental focus.

- Goods and services with a high-yield type of demand elasticity and similar characteristics lying at the core of production.

- Full employment determining growth rates, but without overheating of markets.
- Specialisation correlating with the future potential of the city rather than existing configurations.

- The high growth potential of the city in the city hierarchy of the country (world).

Besides, Kresl identifies two groups of determinants of urban development, namely, quantitative and qualitative. The use of this model seems promising, but with some transformations. First, in order to make the model more understandable, we proposed using the classical input-process-output (IPO) model form, which is typical for process control. Second, the determinants and indicators should be clarified. A possible set of parameters is presented in Table 2 [23].

\section{Methodology. Model 4C + 1S}

The case study methodology is used in the research. This method of intensive analysis of a specific situation involves considering the context and usage of a combination of different (qualitative, quantitative) research methods, data collection, and analysis. The method was described by Eisenhardt [24], Yin [25] and Stake [26], who first proposed an interpretation of the 'case study' essence as a research strategy. To determine what Ekaterinburg's image is now, we used a SWOT analysis technique. This tool is traditionally used in strategic management to identify the object's strengths and weaknesses, as well as opportunities and threats of the external environment. Accordingly, strengths and weaknesses refer to endogenous factors, while opportunities and threats indicate exogenous ones.

As a practical tool for marketing analysis and spatial planning, we propose a $4 \mathrm{C}+1 \mathrm{~S}$ model, developed by analogy with the $4 \mathrm{C}$ model from corporate marketing (Fig. 3).

Table 2

A model of urban competitiveness

\begin{tabular}{|c|c|c|}
\hline Inputs & Processes & Outputs \\
\hline $\begin{array}{l}\text { A positive balance of investment flows; } \\
\text { The share of residents with higher } \\
\text { education; } \\
\text { The share of residents with scientific } \\
\text { degrees; } \\
\text { The proportion of the workforce } \\
\text { employed in research and development; } \\
\text { Immigration of highly qualified } \\
\text { specialists; } \\
\text { Investments in infrastructure; } \\
\text { The provision of housing (investment } \\
\text { in housing) for employees engaged in } \\
\text { research and development }\end{array}$ & $\begin{array}{l}\text { Institutional environment; } \\
\text { World-class scientific events } \\
\text { (conferences, workshops); } \\
\text { Local and international events } \\
\text { related to environmental } \\
\text { protection; } \\
\text { Number and size of higher } \\
\text { education and research } \\
\text { institutions; } \\
\text { Number and size of corporate } \\
\text { departments of research } \\
\text { and development, as well as } \\
\text { corporate universities }\end{array}$ & $\begin{array}{l}\text { Employment (above the national average); } \\
\text { Growth rate (above the national average); } \\
\text { The share of innovative goods and services } \\
\text { in the Gross Regional Product (GRP); } \\
\text { The share of environmentally friendly } \\
\text { products in GRP; } \\
\text { Number of registered intellectual property } \\
\text { items (IPI); } \\
\text { The share of IPI registered in international } \\
\text { patent offices (USA, EU, Japan); } \\
\text { Number of licenses issued for intellectual } \\
\text { property; } \\
\text { Number of innovative start-ups; } \\
\text { Academic entrepreneurship development }\end{array}$ \\
\hline
\end{tabular}

* Source: [23]. 


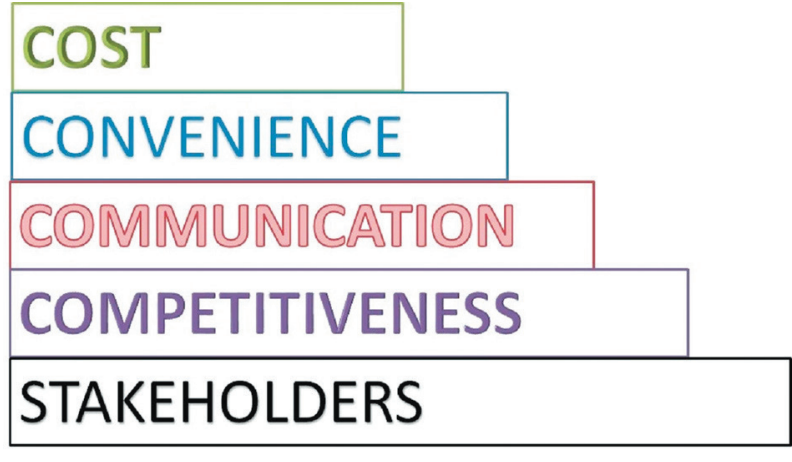

Fig. 3. Model $4 C+1 S$

The first three elements are similar to the $4 \mathrm{C}$ model:

- COST: the cost of living in the city, calculated as a ratio of income and expenditure.

- CONVENIENCE: first and foremost, the infrastructure, but also the supply of all types of public goods and the ecological well-being of the territory. This factor is essential for both residents and visitors of the city. Estimates can often be entirely arbitrary (for example, the characteristic 'green city' does not imply the counting of trees per square kilometre of the area).

- COMMUNICATION: implies strategic communications, i.e., the authorities' ability to successfully present the mission, vision, and strategic plan for the development of the place to the stakeholders.

The latter seems especially crucial in terms of the impact on both internal and external stakeholders. One can list an example of a recent attempt at transport reform in Ekaterinburg, which failed solely because of weak communication with stakeholders. Besides, strategic external communications attract investment flow and human capital from the outside, which is essential for sustainable development of the territory.

As for the other two elements of the model, STAKEHOLDERS substitute CUSTOMER in corporate marketing. COMPETITIVENESS is the object and integral indicator of the success of the place marketing activities. We also used PEST analysis as a marketing tool designed to identify political, economic, social, and technological aspects of the external environment.

\section{Results}

\section{SWOT-analysis}

Endogenous factors were analysed based on the $4 \mathrm{C}+1 \mathrm{~S}$ model; then, we used the PEST methodology to examine the external environment, which involves analysing political, economic, and technological factors. As a factor of convenience of living in this area, we considered three factors: infrastructure, public goods and ecology. We also tried to assess Ekaterinburg's competitiveness in the Russian city hierarchy from the perspective of various internal and external stakeholders. The analysis was conducted in a focus group consisting of students-marketers. The results of the analysis are presented in Table 3.

It should be noted that the results of this SWOT analysis reflect the subjective perception of the external and internal environment factors by residents of the city, who are also young marketing specialists. From the results of the SWOT analysis, we can conclude that Ekaterinburg is an attractive place to live, primarily due to a large number of jobs (including high-yield) and public goods (parks, museums, theatres, cinemas, and nightclubs). The city's weak sides include an unfavourable ecological situation, insufficiently developed urban infrastructure, low level of communication between the municipality and external and internal stakeholders. In general, the city is quite competitive in the eyes of stakeholders within the Russian city hierarchy.

Among the external environment threats, the low rouble rate should be noted, which stimulates the export sectors of the economy but preserves low domestic demand. External political instability poses a threat to economic, cultural and political ties with Western countries and reduces access to modern technologies. If the low birth rate will continue to be compensated for by the flow of migrants, a decline in the workforce's quality will be more prominent. The lack of domestic high tech production threatens the development of the national, regional, and urban economies, which is one of the critical problems of national security.

\section{Analysis of the Experience of Host Cities of Global Sports Events}

Recently, the organisation of global sports events has become an essential element of state policy; many countries are actively fighting for the right to host such activities on their territory, as they provide excellent opportunities for an increase in the competitiveness and international prominence of the country, make a significant contribution to the improvement of its tourist and investment attractiveness.

It is necessary to create a positive image of the place to attract attention to the territory as a favourable one for a sports event. This task requires the development and implementation of the brand. The policy of image creation begins with the attraction of professional human resources: representatives of academic, political, diplomatic, business, and media elites of the re- 


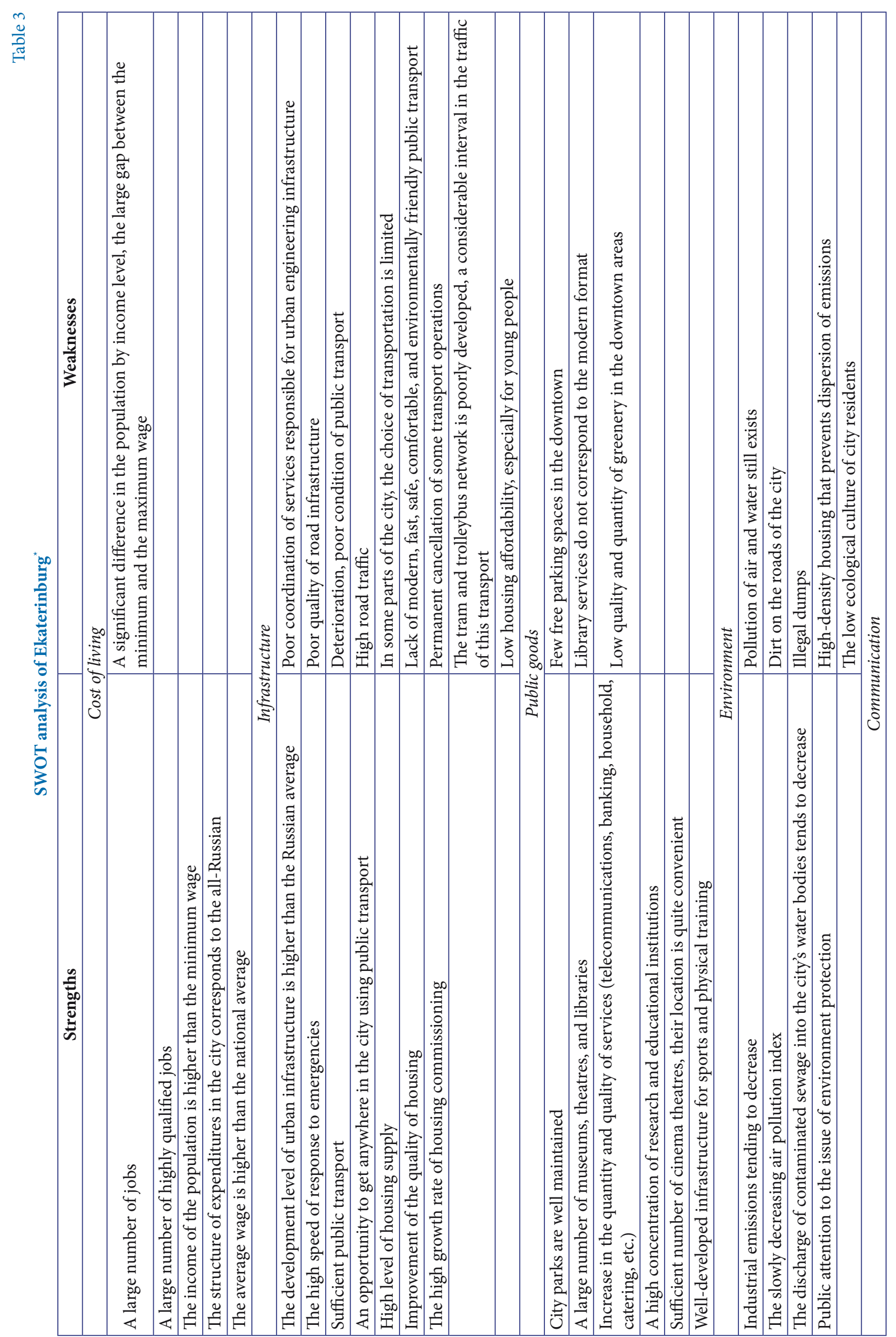




\begin{tabular}{|c|c|c|c|c|c|c|c|c|c|c|c|c|c|c|}
\hline & 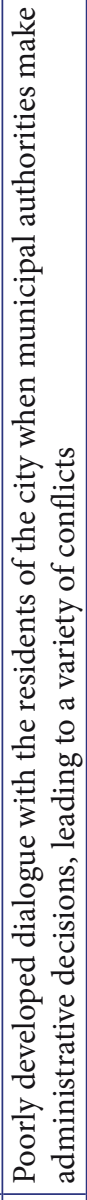 & 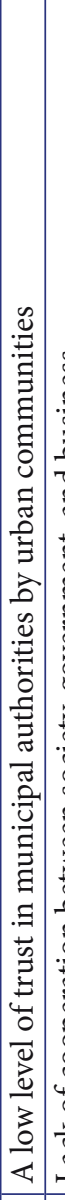 & 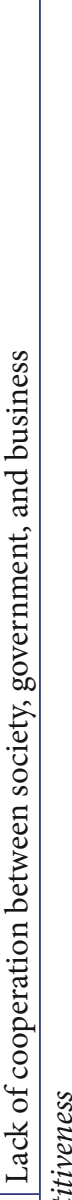 & 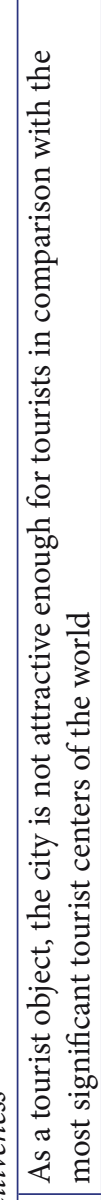 & 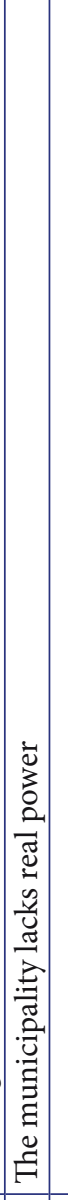 & & 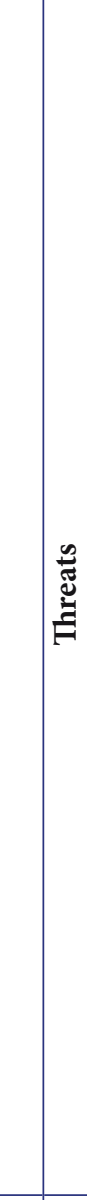 & 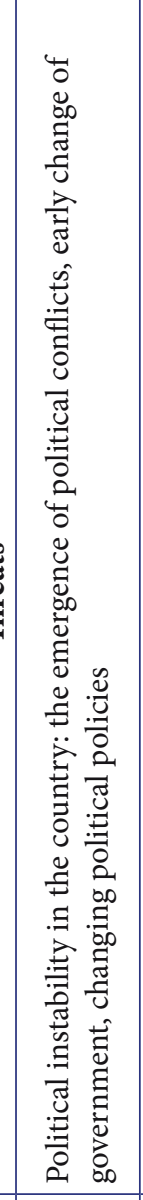 & 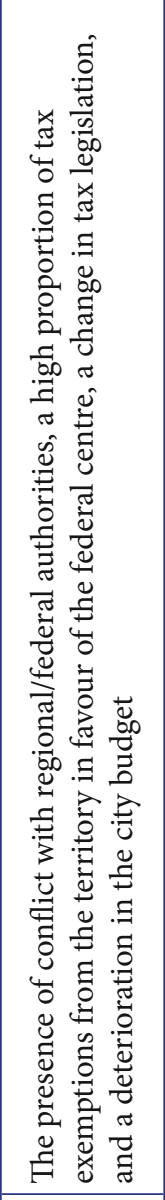 & 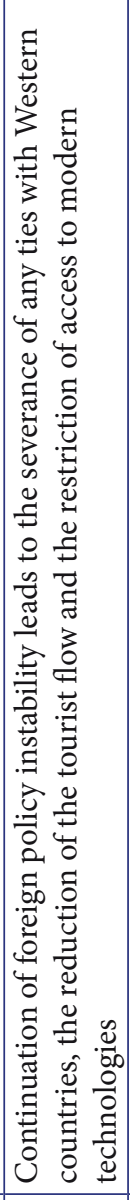 & 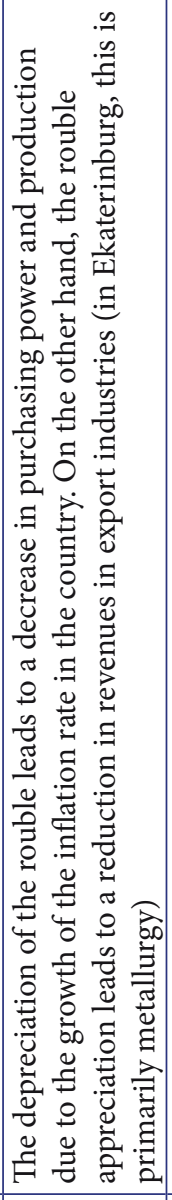 & 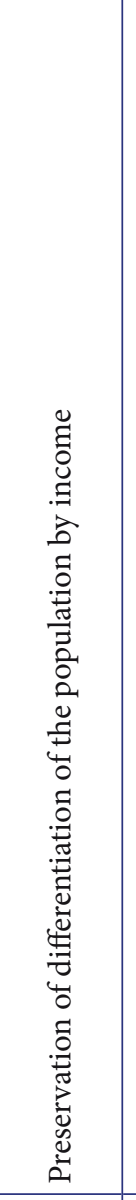 & 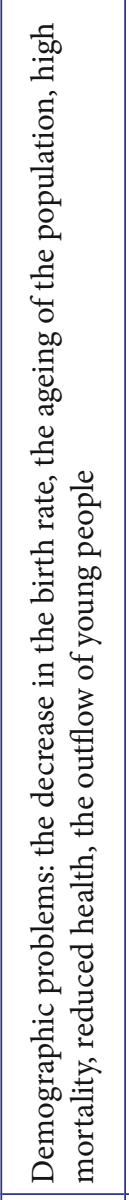 & 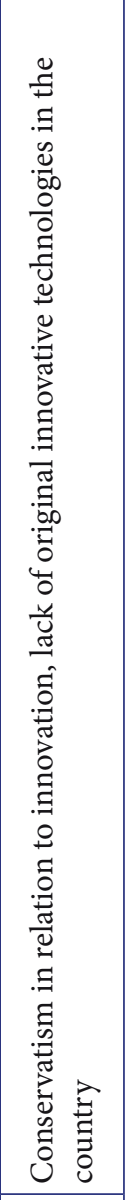 \\
\hline & 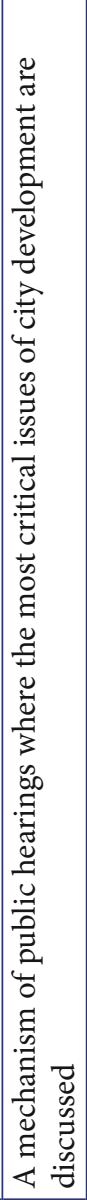 & 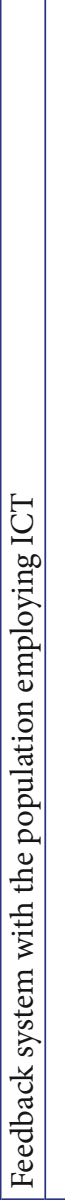 & & 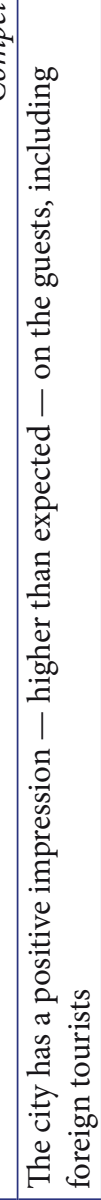 & 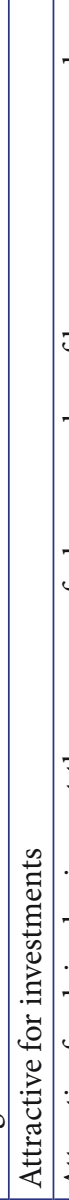 & 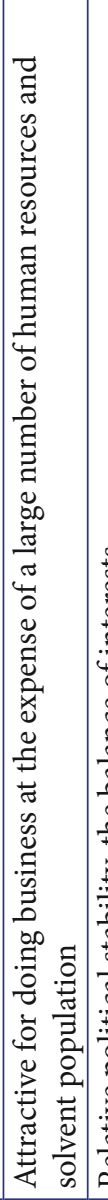 & 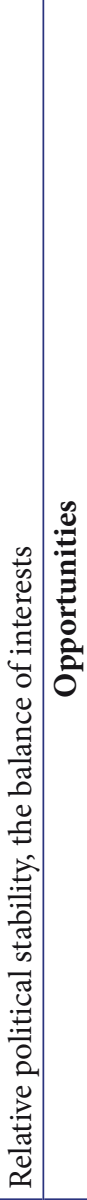 & 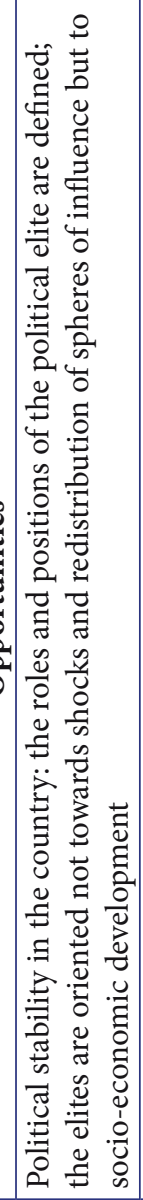 & 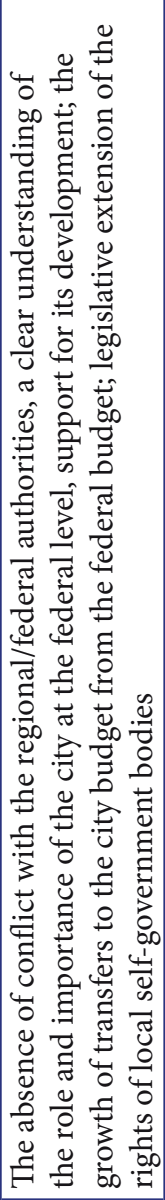 & 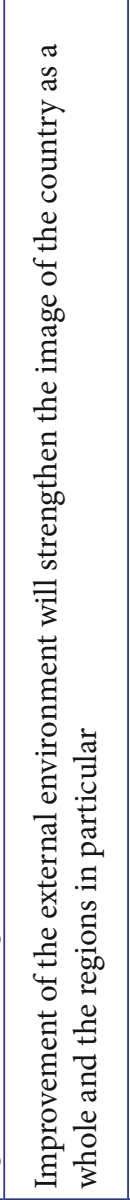 & 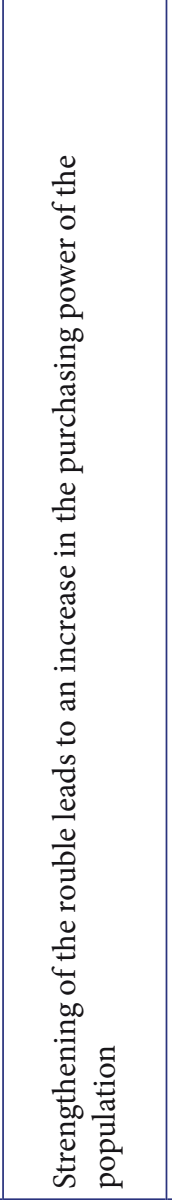 & 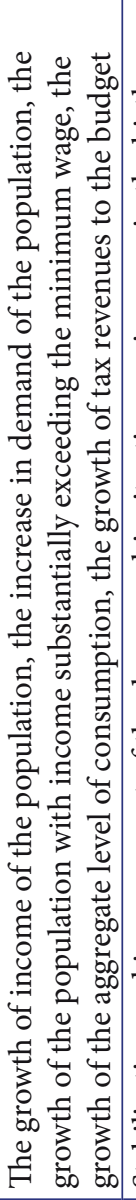 & 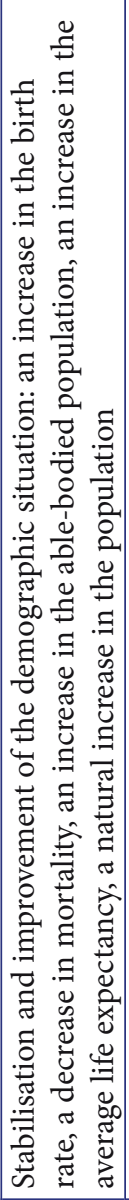 & 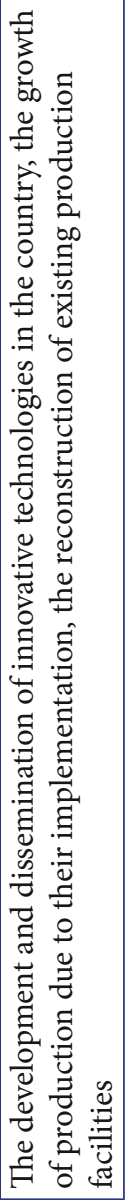 \\
\hline
\end{tabular}


gion and the country. Before starting a campaign for place branding, specialists need to clearly understand what the brand is at the moment, examine what associations and stereotypes are present in different audiences, and, based on this, create a new brand, or 'reconstruct' the old one. If the territory already has a strong brand, it can attract activities that will, in turn, strengthen it [27]. The transformations associated with the development of a well-designed infrastructure give a long-term economic, demographic and social effect throughout the region, contribute to creating a positive event series of the territory and increase its attractiveness.

A vivid example of the competent use of a global event for regional development is the 1992 Olympic Games held in Barcelona. The government of Barcelona sought to use the Olympics for advertising purposes, to designate and strengthen Barcelona, which was previously known only as the capital of the Spanish coastal region Catalonia, and thereby revive the sluggish tourism. The event attracted huge investments. The city authorities were able to conduct several infrastructure reforms: the reorganisation of the public transport system, the improvement of city parks and the coast, the construction of new roads. More than $80 \%$ of the funds were used to implement urban development projects and create new cultural zones rather than sports infrastructure. The city authorities managed to attract long-term investments, which enabled the city to further develop after the Olympics, turning Barcelona into one of Europe's tourist capitals. The image of the place, which had a weak historical identity at that time, was entirely re-considered. Barcelona was presented in the international arena as a modern, innovative, friendly city with its unique style. The promotion of the territory continued after the Olympic Games, focusing on the 'unique culture of Barcelona and its attractiveness as a place for organising premium tours,' the city's leaders were able to position Barcelona effectively as a key Spanish tourist centre offering many options for leisure [28].

Such events as the Olympic Games and the World Cups enable host cities and countries to tell the world their new story. However, the common mistake of host countries of international events is the lack of the idea that they would like to convey after the event. There is no developed marketing concept for further advancement of the territory. A vivid example is the 2004 Olympic Games in Athens. As it turned out, after the Olympics, Athens did not have developed stories, which could be included in the media plan or used for strategic purposes. Marketing activities, held before and during the Games, should have continued after the event, focusing on improving the city's original features and highlighting its modern properties acquired during the preparation for the Games. Moreover, Greece still attracts tourists by conveying the traditional message about the sea, sand and ruins [27]. Thus, specialists need to develop a successful concept and support its development after the event to maintain tourist and investment flow.

Sports events give the city a push in development, building a positive image, as well as an idea that can unite residents and emphasise the uniqueness of their territory. Until 2010, Africa was considered a 'hopeless continent,' which is not capable of organising and conducting something serious; now, in the eyes of the world community $^{1}$, it is a continent of opportunities, a continent for investment and successful business. At the stage of preparation for the FIFA 2010, a real breakthrough was made in the development of the infrastructure necessary for the South African Republic: new roads, airports, hotels, shopping centres were built.

Thanks to the World Cup, the tourism industry has been developed as well. According to Danny Jordaan, the president of the 2010 World Cup organising committee, after the World Cup, all the fans returned to their homeland and shared their impressions of South Africa with their families and friends - it was an excellent advertisement for South Africa [29]. The example of the World Cup 2010 confirms that as residents and visitors remember such events for a long time, they promote the dissemination of positive information in the future and contribute to the emergence of tourists' flow.

Until 2010, the image of the South African Republic was negative. However, thanks to the Championship, South Africa has earned the reputation of a country that is ready to host events on a global scale, has sufficient technological and information training. All this is very important not only for further economic development but also for citizens. The championship was held under the slogan 'African World Cup.' It became the reason for national pride, which united the whole country, became some kind of national idea for South Africa.

Hosting global events plays a vital role in the revival of cities and often becomes the beginning

\footnotetext{
${ }^{1}$ In 2000, The Economist gave Africa such an assessment, but already in 2011, the magazine revised it to 'rising,' and in March 2013 - to 'aspiring' [34].
} 
of a branding campaign. As an example, we can list the organisation of the 2013 World Summer Universiade in Kazan. This event became a catalyst for changes in the city and firmly established the idea of Kazan as a significant sports centre of Russia in the international sports community. In the video presented before the Universiade, Kazan appears to be a place where different cultures and religions converge and peacefully coexist. Slogan: 'Kazan is a thousand worlds of new.' Kazan thoroughly prepared for the sports event: dozens of unique sports facilities were built, the urban infrastructure was improved.

As the experts noted in an interview conducted by the Center of Advanced Economic Research in the Academy of Sciences of the Republic of Tatarstan, the Universiade contributed to increasing the competitiveness of the entire Republic and the economic value of the brand [30]. Along with this, the investment attractiveness of the city also increased. Some experts draw attention to the fact that the Universiade had the most significant impact on the tourism sector. The increase in the tourist flow by $15 \%$ was possible because the city became more comfortable and attractive for tourists; more hotels and entertainment infrastructure appeared. In November 2013, Kazan was awarded a special prize as the best place in the world for international sports events, along with London, Dubai, and Oakland. According to experts, Universiade acted as a business card of the city or portfolio of the Republic. The majority of experts gave a sufficiently high assessment of the event in terms of the Republic's external image, raising awareness, tourism and investment attractiveness and competitiveness of the Republic.

The infrastructure created for the Universiade made it possible to adequately host the FINA World Championship 2015, which, in turn, also helped attract tourists to the Republic of Tatarstan. The World Championship in Water Sports became a worthy page in the history of the city's sport, strengthening Kazan's status as one of Russia's sports centres and the image of the city at the world level.

The Republic of Tatarstan has a unique tourist and recreational potential, which is determined by abundant natural resources, cultural and historical heritage, diverse ethnographic composition, and favourable geographical location. These factors empower the attraction of the territory for large-scale international events, as well as the high level of development of the sport. Kazan is an example of a city whose sporting potential has been gradually evolving into a sustainable brand. In addition to organising mega-events, the author- ities of Kazan ensure the development of sports not only at the regional but also at the all-Russian level, opening national sports and training centres, higher educational institutions and creating conditions for training the clubs-champions, revealing the potential of the declared brand 'Sports Capital of Russia' [31]. It means that sports mega-events can serve as a basis for development of the image of the city and strengthening the created image within the country and worldwide.

An example of the successful implementation of the concept of place marketing, which cannot be overlooked, is hosting the Winter Olympic and Paralympic Games in Sochi. It is the first Russian place marketing project successfully implemented. The application campaign aimed to win the right to host the Olympics 2014. The project's ultimate goal was to stimulate the development of the country's southern territories [32].

The target audience was the International Olympic Committee members, international sports federations, global media, the Russian business community, residents of Sochi, and Russian society. At the core of the marketing activities was the dialogue with all target audiences. They all had somewhat different interests. For example, international sports organisations required an experience of hosting world or European level events, developed infrastructure, a positive image of athletes and coaches of the country, the popularity of sports in general, the ability to provide a high level of service, and security. The main marketing tasks were the adjustment of the perception of Sochi as a summer holiday destination towards a year-round resort and raising of awareness of the city outside the Russian Federation. Since the target groups differ in their cultural and social context and expectations, the different key messages were formed for each of them. The communication strategy used all the main channels of communication: electronic and print media, the Internet, television, radio, and outdoor advertising. One of the essential elements of the promotion was BTL activities. The Sochi 2014 image events were aimed at dispelling negative stereotypes, images that had long been consolidated in the minds of foreigners. For this purpose, clips were created targeting foreign audiences; their main idea was "Russia's openness".

Having won the right to host the Olympic Games, Sochi was able to modernise the city's infrastructure and develop at an accelerated pace, which made it possible to take the event with dignity. Most of the visitors associated the Winter Olympic Games in Sochi 2014 with Russia's success in sports. The Olympics in Sochi was of 
great importance for Krasnodar Krai; it received a massive flow of investments that had a positive impact on its functioning and development. Modernisation of the infrastructure and construction of ski slopes and other sports facilities enabled an increase in tourism revenues in winter, evenly distributing tourist flows by seasons. As a result, Sochi became a prestigious year-round resort on a global level. The rebranding of the city and the improvement of its image in the eyes of the world community brought Sochi to the number of significant geopolitical centres [33].

Thus, as part of the preparation and conduct of a major international sports event, all efforts are aimed at improving the industrial, social, institutional and environmental infrastructures of the region, creating and maintaining its image as a means of attracting investments in the development of the city and the whole region. At the same time, the territory is gradually turning into a product sold to the domestic and foreign markets. As a result of the organisation of global sports events, many new infrastructure facilities appear that can seriously change the face of the city and improve the quality of life of its residents; at the same time, it is necessary to take into account the short period of sports events. For example, the 2014 Olympics was a significant event. Still, on its basis, it became possible to achieve the strategic development of the city of Sochi as a mountain-climatic resort of world-class competitiveness. It is necessary to understand how an object will work in the future, develop a concept for the promotion of the territory, and properly position it; otherwise, investors will not be interested in the event. When planning and organising major events, one must consider the actual positive and negative experiences. An essential condition for success is the coordination of government and private investors' actions in the framework of a single strategy based on the model of sustainable development.

\section{Conclusions and Discussion}

Identified strengths and weaknesses of the city enabled the formulation of development directions that require special attention:

1. Improvement of the city's transport system with the priority of developing public transport, environmentally neutral vehicles; provision of comfortable and secure movement through the city, including low-mobility groups of the population. Priority in these conditions is the search for solutions to reduce the negative environmental effect of transport, as well as the time spent on various trips. The city population should be involved in the discussion of the plans for the con- struction and reconstruction of the street-road network. It is also necessary to inform the residents promptly about the measures taken to upgrade the city's transport system.

2. Creation of comfortable living conditions and environmentally sustainable urban systems for the population. This task includes a vast range of activities aimed at the greening of urban transport, the implementation of modern recycling methods, and the rehabilitation of industrial zones. The latter is exceptionally relevant in light of the fact that Ekaterinburg is essentially an old industrial city. Accordingly, industrial zones are located quite close to the modern city centre. The experience of rehabilitating industrial zones can be further used in former industrial areas in Russia and abroad.

3. Maintenance of public consensus, increase in the effectiveness of local government, and improvement of the system of partnership between state power institutions and local communities. To achieve this goal, it is first necessary to create an effective communication strategy (including digital space), and a participative culture of the population.

Satisfaction of the growing needs of the population by improving the comfort of the living environment, upgrading the safety of housing and engineering infrastructure, improving the city's energy efficiency, enhancing the quality of public services.

Formation of the image of the global sports centre implies not only the sport of high-performance sport but also the development of a multivariate system of physical education for various categories and groups of the population, the motivation for physical training and sports as the most critical components of a healthy lifestyle.

At the current stage, it is essential to determine the vision of the future of the city. One option is the centre of business tourism or the industry of meetings. It is subdivided into several sectors, forming the concept of the 'MICE industry' (Meetings, Incentives, Conferences, Exhibitions). Thus, the concept of business tourism includes the organisation and support of both private business visits and hosting of international congresses, symposia, conferences, and exhibitions. Interest in the development of business tourism is growing throughout Russia, as it is one of the most promising and highly profitable types of tourism. It is characterised by high and stable growth and resistance to the impact of economic, political, climatic, weather, and other factors.

The dynamically developing business infrastructure facilitates Ekaterinburg's emerging im- 
age as a centre for international and Russian business communications. By the quantity of trade, office, or logistics space per capita, Ekaterinburg is the second largest in Russia after Moscow. Almost all the largest retailers are represented in the city. In terms of the number of leased offices annually, Ekaterinburg has overtaken St. Petersburg. In the central part of the city, a large-scale project 'Ekaterinburg-City' began, which implies the construction of the largest business centre outside Moscow. Ekaterinburg ranks third in the country, after Moscow and St. Petersburg, by the number of diplomatic offices, now there are 23 consulates in the city. The SCO and the BRICS summits have shown Ekaterinburg's readiness to become a reliable platform for international and Russian business communications.

Another option is industrial tourism. The city has several historical industrial sites (for example, Verkh-Isetsky Plant), which could become unique tourist sites with the proper investment. Reprofiling will make it possible to turn these sites from a source of problems for the city (primarily environmental) into a source of income. Similar facilities exist in the nearby cities (for example, a metallurgical plant constructed in the 18th century in Nizhny Tagil, which is now gradually being destroyed). Unique historical and natural objects of Ekaterinburg and its environs - Sevastyanov's House, Leaning Tower of Nevyansk, the border of Europe and Asia, Lake Beszdonnoye, and many others - could become complementary elements of the primary specialisation.
The development of science and culture is an integral part of the post-industrial urban strategy. Ekaterinburg lacks globalisation (in the proper sense of the word). The mobility of intellectual workers and the exchange of knowledge with the most important international research centres will allow the city to reach a fundamentally new level of development. Besides, an important task is to create a comfortable environment for specialists involved in the process of knowledge generation. As an example, we can cite the idea of creating small 'townships of scientists' within the urban agglomeration, where people can not only live but also generate new ideas in the atmosphere of creativity. Improving the quality of the urban environment may also stop the 'brain drain' that has been going on in Russia since the beginning of the 1990s.

With the development of place marketing, this area of knowledge has ceased to be the exclusive domain of business. Urban marketing is a dynamically developing field, and marketing strategy is becoming a critical condition for the successful development of a modern city. However, the contribution of the article is not limited to the development of practical recommendations. The proposed 4C $+1 \mathrm{~S}$ model can be used as a methodological basis for the development of urban marketing strategies around the world. With the accumulation of practical experience of implementation and changes in the environment, it will inevitably undergo transformations. In our opinion, it is a perspective direction for future studies in urban marketing.

\section{References}

1. Berg van den, L. \& Braun, E. (1999). Urban Competitiveness, Marketing and the Need for Organising Capacity. Urban Studies, 36(5-6), 987-999. DOI: 10.1080/0042098993312.

2. Zenker, S. (2009). Who's your target? The creative class as a target group for place branding. Journal of Place Management and Development, 2(1), 23-32. DOI: 10.1108/17538330910942771.

3. Merrilees, B., Miller, D. \& Herington, C. (2009). Antecedents of residents' city brand attitudes. Journal of Business Research, 62(3), 362-367. DOI: 10.1016/j.jbusres.2008.05.011.

4. Kavaratzis, M. \& Hatch, M. J. (2013). The dynamics of place brands. Marketing Theory, 13(1), 69-86. DOI: $10.1177 / 1470593112467268$.

5. Braun, E., Kavaratzis, M. \& Zenker, S. (2013). My city - my brand: the different roles of residents in place branding. Journal of Place Management and Development, 6(1), 18-28. DOI: 10.1108/17538331311306087.

6. Zhou, L. \& Wang, T. (2014). Social media: A new vehicle for city marketing in China. Cities, 37, 27-32. DOI: 10.1016/j. cities.2013.11.006.

7. Pankrukhin, A. P. (2006). Marketing territoriy. 2-e izdanie [Place Marketing. 2nd edition]. St.-Petersburg: Piter, 416. (In Russ.)

8. Bystrova, T. \& Kochetkov, D. (2017). Branding as an identification of the territory potential: insufficiency of constructivist approach. Proceedings of the Second International Conference on Economic and Business Management (FEBM 2017), 33, 907-916. DOI: https://doi.org/10.2991/febm-17.2017.122.

9. Porter, M. E. (1990). The Competitive Advantage of Nations. New York: Free Press, 855.

10. Porter, M. E. (2000). Location, competition and economic development: local clusters in a global economy. Economic Development Quarterly, 14, 15-34.

11. Krugman, P. (1994). Competitiveness: a dangerous obsession. Foreign Affairs, March/April, 28-44.

12. Krugman, P. (1996). Making sense of the competitiveness debate. Oxford Review of Economic Policy, 12, 17-25. 
13. Huggins, Robert, Luo, S. \& Thompson, P. (2014). The competitiveness of China's leading regions: Benchmarking their knowledge-based economies. Tijdschrift Voor Economische En Sociale Geografie [Journal of Economic \& Social Geography], 105(3), 241-267. DOI: 10.1111/tesg.12065.

14. Malecki, E. J. (2007). Cities and regions competing in the global economy: Knowledge and local development policies. Environment and Planning C: Government and Policy, 25(5), 638-654. DOI: 10.1068/c0645.

15. Maskell, P. \& Malmberg, A. (1999). Localised learning and industrial competitiveness. Cambridge Journal of Economics, 23, 167-185.

16. Storper, M. (1997). The Regional World. Territorial Development in a Global Economy. New York: Guilford Press, 338.

17. Begg, I. (1999). Cities and competitiveness. Urban Studies, 36, 795-809.

18. Budd, L. (1998). Territorial competition and globalisation: Scylla and Charbydis of European cities. Urban Studies, 35(4), 663-686.

19. Ciampi, C. A. (1996). Enhancing European competitiveness. Banca Nazioanle Di Lavoro Quarterly Review, 49(197), 143-164.

20. Gordon, I. R. (1999) Internationalisation and urban competition. Urban Studies, 36, 1001-1016.

21. Lever, W. (1993). Competition within the European urban system. Urban Studies, 30, 935-948.

22. Kresl, P. (1995). The determinants of urban competitiveness. In: P. Kresl, G. Gappert (Eds.), North American Cities and the Global Economy: Challenges and Opportunities (pp. 45-68). London: Sage.

23. Kochetkov, D. (2017). Thoughts about the Future of Russian Cities: Evidence from Ekaterinburg. In: Proceedings of the 13th European Conference on Management, Leadership and Governance (pp. 245-252). London.

24. Eisenhardt, K. M. (1989). Building Theories from Case Study Research. The Academy of Management Review, 14(4), 532. DOI: $10.2307 / 258557 /$

25. Yin, R. K. (2003). Case Study Research: Design and Methods. Thousand Oaks, CA: SAGE Publications, 181.

26. Stake, R. E. (2008). Case studies. In: N. Denzin, Y. Lincoln (Eds.), Strategies of qualitative inquiry. 3rd ed. (pp. 119150). Thousand Oaks, CA: SAGE Publications.

27. Dinnie, K. (2011). City Branding: Theory and Cases. London: Palgrave Macmillan, 239.

28. Kotler, P. (1999). Marketing Places Europe: How to Attract Investments, Industries, Residents and Visitors to Cities, Communities, Regions and Nations in Europe. London: Financial Times Prentice Hall, 302.

29. Agapov, A. (2013). Danny Jordaan: World Cup 2010 opened up emerging countries for big sport. RIA Novosti. Retrieved from: https://rsport.ria.ru/interview/20130126/641754101.html (Date of access: 20.08.2020). (In Russ.)

30. Ermolaeva, P. O., Noskov, E. P. \& Shakirova, A. F. (2015). Influence of sports mega events on formation of external image of the Republic of Tatarstan: expert community assessments. Elektronnyy Ekonomicheskiy Vestnik Tatarstana [Electronic Economic Newsletter of the Republic of Tatarstan], 2, 29-37. (In Russ.)

31. Sobol, E. (2015). Leonov: Kazan is technically ready to host the Summer Olympic Games. RIA Novosti. Retrieved from: https://ria.ru/20150725/1147442862.html (Date of access: 20.08.2020).

32. Orlov, A. B. (2012). An example of the city of Sochi in the formation of the sporting image of the territory. Fizicheskaya kultura, sport - nauka i praktika [Physical Education, Sports - Science and Practice], 4, 82-86. (In Russ.)

33. Bredikhin, A. V. (2015). Rebranding the city of Sochi: The Olympic image. In: Brending malykh i srednikh gorodov Rossii: opyt, problemy, perspektivy. [Branding of small and medium-sized cities in Russia: experience, problems and prospects] (pp. 109-111). Ekaterinburg: Publishing House of the Ural University. (In Russ.)

34. Dupoux, P., Ermias, T., Heuzé, S., Niavas, S. \& von Koschitzky Kimani, M. (2014). Winning in Africa: From Trading Posts to Ecosystems. Boston Consulting Group. Retrieved from: https://www.bcg.com/publications/2014/globalization-emerging-markets-winning-africa-trading-posts-ecosystems (Date of access: 20.08.2020).

\section{About the Authors}

Dmitry M. Kochetkov - Head of the Office for Coordination of Activities of the Federal Project «Infrastructure», Department of Project Management, Ministry of Science and Higher Education of the Russian Federation; https://orcid. org/0000-0001-7890-7532; Scopus ID: 57194605735 (11, Tverskaya St., 125009, Moscow, Russian Federation; e-mail: kochetkovdm@hotmail.com).

Darko Bozha Vuković - Dr. Sci. (Econ.), Professor, Geographical Institute «Jovan Cvijic» of the Serbian Academy of Sciences and Arts; http://orcid.org/0000-0002-1165-489X; Scopus ID: 57031563800 (9, Djure Jaksica St., Belgrade, 11000, Serbia; e-mail: vdarko@hotmail.rs).

Elizaveta A. Kondyurina - Brand Manager, Pokrovskiy Passage Ltd.; https://orcid.org/0000-0001-6537-1978 (4, Rosa Luxemburg St., Ekaterinburg, 620075, Russian Federation; e-mail: s16022014@gmail.com).

\section{Информация об авторах}

Кочетков Дмитрий Михайлович - начальник отдела координации мероприятий федерального проекта «Инфраструктура», Департамент проектной деятельности, Министерство науки и высшего образования Российской Федерации; https://orcid.org/0000-0001-7890-7532; Scopus ID: 57194605735 (Российская Федерация, 125009, г. Москва, ул. Тверская, 11; e-mail: kochetkovdm@hotmail.com). 
Вукович Дарко Божа - доктор экономических наук, профессор Географический институт «Йован Цвиджич» Сербской академии наук и искусств; http://orcid.org/0000-0002-1165-489X; Scopus ID: 57031563800 (Сербия, 11000, г. Белград, ул. Джуре Якшича, 9; e-mail: vdarko@hotmail.rs).

Кондюрина Елизавета Александровна - бренд-менеджер, Покровский пассаж; https://orcid.org/0000-00016537-1978 (Российская Федерация, 620075, г. Екатеринбург, ул. Розы Люксембург, 4; e-mail: s16022014@gmail.com).

Дата поступления рукописи: 15.06.21

Прошла рецензирование: 10.08 .21 Принято решение о публикации: 24.09.2021.

Received: 15 Jun 2021.

Reviewed: 10 Aug 2021.

Accepted: 24 Sep 2021. 